\title{
Corporate Social Responsibility in Malaysia
}

\author{
Sheikh Muhamad Hizam ${ }^{1}$, Zulkarnian Iylia Syazana binti Othman ${ }^{1}$, Mohammad Mohammad Amin ${ }^{1}$, Zalina \\ Zainudin $^{1} \&$ Mohd Faiq Abdul Fattah ${ }^{1}$ \\ ${ }^{1}$ Business School, Universiti Kuala Lumpur (UniKL) Jalan Gurney, Malaysia \\ Correspondence: Sheikh Muhamad Hizam, Business School, Universiti Kuala Lumpur (UniKL) Jalan Gurney, \\ Kampung Datuk Keramat, 54000 Kuala Lumpur, Wilayah Persekutuan Kuala Lumpur. Malaysia.
}

Received: April 30, 2019

doi:10.5430/ijfr.v10n5p381
Accepted: May 30, 2019

Online Published: June 11, 2019

URL: https://doi.org/10.5430/ijfr.v10n5p381

\begin{abstract}
The field of corporate social responsibility (CSR) has developed exponentially in the last decade and is consistently getting to be a worldwide slant. Corporate social responsibility (CSR) has become a worldwide matter around the world that comes about an expanding number of studies on CSR universally as well as in Malaysia. Furthermore, the importance of CSR practices was emphasized by companies in order to ensure its sustainability in corporate world which are focused on (a) environment, (b) social dimension sustainability, (c) economic advancement, (d) stakeholder behaviour and (e) ethical evolution of society. In this manner, this paper gives a concept of CSR writing that has been conducted in Malaysia to assess the execution of CSR among organizations in Malaysia. It is presently anticipated that organizations expressly take into consideration all perspectives of their execution, not as it were their money related comes about, but moreover their social and commerce environment. Subsequently, most of organizations are presently locked in genuine endeavours to characterize and coordinated CSR into all perspectives of their businesses and exhibitions. The point of our think about is to get it this slant in Malaysia and particularly to explore (i) the status of CSR in Malaysia; (ii) different CSR practices in Malaysia; and (iii) future dissemination of CSR in Malaysia. Finally, over the last few decades, Malaysia has been gradually improving its alignment with global management practices such as quality management and ISO 9002.
\end{abstract}

Keywords: corporate social responsibility, perception

\section{Introduction}

Corporate social responsibility (CSR) has been a growing field of interest in recent years and consequently, a growing number of calls for companies to address sustainability in their business policies and practices, as well as to disclose on what and how well they are doing. CSR disclosure can be defined as the provision of information regarding human resource aspects, products and services, involvement in community projects including philanthropic activities and environmental matters. It is also conceptualized as the construct describing the relationship between companies and society. CSR has become a trend and popular in a society whereby it is a crucial function in every company to organize a program related to social projects environment. The questions of why CSR has become a viral factor in such a way certain companies getting involved in these matters are because it is one of the great initiatives for the growth in business and it could lead to the enhancement of productivity in various aspects. CSR gradually expanded to improve the work environments and equity of employees. Perceptions of CSR are based on the objectives of corporations such as sustainable management and contributions to the society, which is the source of corporate profits. Most companies nowadays are facing important challenges due to the economic crisis. In order to overcome the critical challenges, companies need to consider themselves as socio-economic agents contributing to the community (Khan, et al., 2016; Sallayici \& Kolayis 2018). It is considered as a strategy for the companies' economic, social and environmental development. Therefore, the purpose of this study is to measure the findings from the existing research on the positive impact of CSR towards the business of a company. The research contributes to a fundamental explanation of how the community could be empowered to become important criteria of CSR practices which will be driven to a better atmosphere if both firms and communities work together towards a sustainable livelihood. The hypothesis of this study is based on good CSR practices will affect the performance in a company (Jermsittiparsert \& Sawasdee 2012; Rozaimie, Huzaimah \& Morni 2016). 


\section{Literature Review}

According to Baker, M. (2010); Teoh, S. Y., Thi, L. S., Teh, Y. K. (2016), that Corporate Social responsibility (CSR) is a genuine commitment by organizations to contribute their quarter to the sustainable development and to improve the quality of life in the work place and in the society at large. Recently, there is rapid development of CSR in Malaysia and Malaysia has become one of the most active emerging economies that involve in corporate social responsibility. However, the definition of corporate social responsibility (CSR) consists of five important aspects: (a) environment, (b) social dimension sustainability, (c) economic advancement, (d) stakeholder behaviour and (e) ethical evolution of society. It is a business approach that contributes to sustainable development, social and environmental benefits for all stakeholders. Ibrahim, Zam Zuriyati, Jamal, Norlia (2013) has carried out a content analysis to examine the importance of consumer products and plantation industry. It is concluded that the level of disclosure is still low-level category in disclosing the CSR activities although the number of companies disclosed their CSR activities was high for both products and plantation industries. It also revealed a gap between the maximum and minimum number of sentences for CSR disclosure in the business organizations. However, the field of CSR has been defined in several studies in different area of CSR (Ali \& Haseeb, 2019; Garriga, Melé, 2004; Radzi, N. A. M., Lee, K. E., Halim, S. A., Siwar, C. 2018; Jr \& Peñol 2018), analysis of CSR approaches, CSR in supply chains, standardization of CSR, CSR in large organizations and CSR in small businesses. Furthermore, the global diffusion of CSR is accelerating, and the global understanding of CSR is slowly aligning and converging. There are numerous CSR initiatives and many non-governmental organizations (NGOs) such as Malaysia Trade Unions Congress (MTUC), the Federation of Malaysia Consumers Association, Consumer Association of Penang, Malaysian Nature Society and WWF Malaysia contribute to a growing publicity about CSR and raise social responsibility as well as environmental awareness. According to Ramasamy, B., and Ting, H. W. (2004); Yusoff, W. F. W., Adamu, M. S. (2016); Khan \& Aslam (2017), furthermore assert that CSR business in Malaysia will be especially needed in terms of assisting organization's success in the long run. One of the core challenges that the Government and policy-makers are facing is to understand the concept of CSR, to comprehend the understanding of CSR by the wider public, and to identify the type of CSR activities practiced in Malaysia and the type of assistance the Government can offer to motivate the industries to adopt CSR (Ibrahim, A. I. A., Rashid, M. (2002; Jermsittiparsert, 2013); Hasan, N. A. M. (2016). Over the last few decades there has been a growing public awareness on the role of Corporate Social responsibility (CSR) in society (Reverte, 2009; Jermsittiparsert, Sriyakul \& Pamornmast 2013; Chong, S. Y. C., Wad, P. 2017).

According to Chandler (2001), beyond making profits, companies are responsible for the totality of their impact on people and the planet. Ahmad, J., Binti, N., Rashid, A., Gow, J. (2017), defines CSR as the obligation of managers to choose and act in ways that benefit both the interests of the organization and those of the society as a whole. In addition, Abdullah, A., et al., 2016, has defined CSR as a process of disseminating the social and environmental effect of company's economic behaviours to particulars stakeholders within a society and to society at large (Pahi, Shah, Ahmed \& Hartani, 2016; Samaila, Uzochukwu \& Ishaq 2018). In short, CSR can be concluded as an accountability of organization not only in making the economic return but also the accountability of organization towards the employee welfare, community involvement, product development, energy safe and environmental protection. Thus, the accepted definition of corporate social responsibility is a concept where the organizations use their resources in a good manner, compliance with the legal requirement and also consider and respect the communities and the environment. Joseph, C., et al., (2016); Khan \& Mingyi (2018), Corporate Social Responsibility (CSR) is the obligation of the decision makers in corporate organizations to take actions, which protect and improve the welfare of the entire society along with their own interest (Jermsittiparsert, Sriyakul \& Rodoonsong 2013).

\section{Methodology}

This study aims the research to examine how socially responsible is the Malaysian organizations system to the current problem of organizations in Malaysia. The period covered in this study is that of Malaysians organizations. The study used percentages of data analysis.

\subsection{Data Presentation, Analysis Findings and Discussion}

The results presented below are based on the data collected from Malaysian organizations.

\subsubsection{Analysis and Findings}

The implementation of the outreach programs as well as coordinate communication campaigns have shown positive results. Malaysian organizations have approved total financing amounting to RM25.7 billion and has assisted more than 15,000 entrepreneurs. As at 2016, below is the financing records for the Malaysian organizations: 


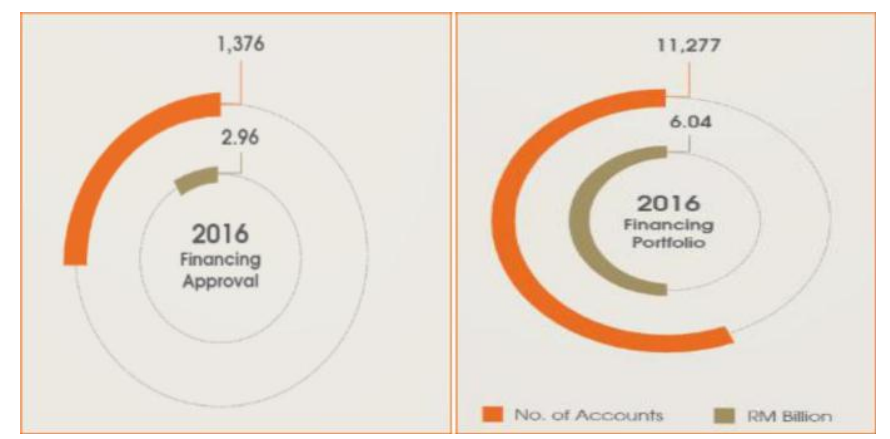

\section{Customer Satisfaction}

In ensuring customer satisfaction, a survey has been conducted and the customer satisfaction index shows an increasing positive result in 2016 than year 2015 as shown in graph below:

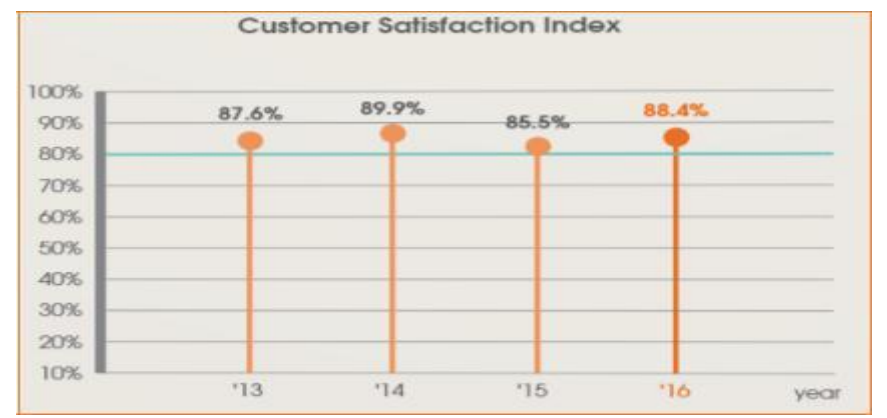

\section{Social Media Acknowledgement}

Malaysian organizations efforts in promoting the Y-Biz Challenge as well as "Your Success Our Story" features have attracted the media to the organizations. They received 36 media mentions via TV, radio, social media platform and printed media after their advertising on 2016.

\begin{tabular}{|l|c|c|}
\hline Type of Media & No. of Clips & Roach \\
\hline TV & 3 & 2 million viewers \\
\hline Social Media & 17 & 64 pax \\
\hline Newspaper & 13 & 7.2 million readers \\
\hline Total & 36 & \\
\hline
\end{tabular}

\section{Employee Satisfaction Score}

Towards the end of December 2016, Malaysian organizations has rolled out an Employee Satisfaction Survey with a total of 43 questions to gauge employee's satisfaction within the organizations as an employer. Below image show the findings of the organizations 2016/2017 survey. Most employees were more than $77.4 \%$ positively satisfied and engaged with the organizations. From the organizational perspective, it indicates that Malaysian organizations is a 'good' company with the opportunity to become a "great" company when the overall satisfaction rating goes beyond $85 \%$. 


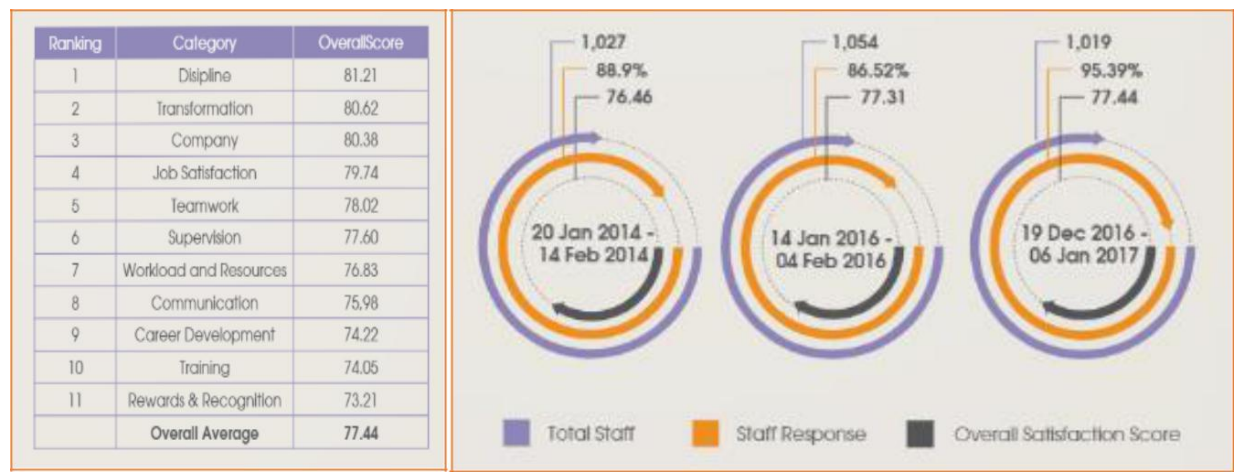

\section{Conclusion}

From this research which is an attempt to examine the comprehensiveness of CSR disclosure disclosed by the companies via the annual or sustainability report, it can be concluded that public listed companies in Malaysia are starting to realize the importance of social responsibility as a way of communication with stakeholders and with the community in the performance of their businesses. It has also revealed there was a gap between the minimum and maximum of CSR disclosure in the report. It is believed that the relationship between community and Corporate Financial Performance (CFP) is significantly positive with no negative response from stakeholders when the companies spend specific financial resources to support the society development. The companies are gaining more support and being well-recognized by the society by their further involvement in national event, education funds, the development in a rural development and many other social activities. As for the marketplace and the environment, the engagement with an environment issues could add enough value to the reputation of the companies for both industries. Therefore, these two dimensions is positively related with the CFP and it is found that it will be worth the impact in investing for their product development in the market. For the workplace (employee engagement) dimension, it is positively associated with the financial performance of a company it is also important to adapt a motivation to the employees by giving them rewards, organized a specialty loyalty program, a conducive training and enhanced on the work-life balance environment as their high productivity towards the sustainable of a business.

Although most of these companies viewed CSR as an additional cost and found it not to be relevant to their business strategy, the involvement of CSR activities has opened the "eye" of more companies in managing their business to a better financial reputation and performance impact. The government agencies could also support the companies to involve in CSR activities and make it disclose later to attract positive response from stakeholders and other institutional investors. For 2018 and based on market development and needs, organization is focusing on providing financing in the wholesale and retail, business services, education and healthcare and in manufacturing sectors. Malaysian organizations will continue to offer innovative financing solutions in addition to various developmental programs with the objective of achieving the $41 \%$ contribution target to the nation's GDP by the year 2020 .

This practices among companies in a developing country need to be increased as it is potentially benefited not only for business itself, but also towards the growth in a prospect of economy especially within Malaysia.

For a better highlight in the findings of the research, it is concluded that the CSR disclosure have given a positive impact to the business development of the organizations:

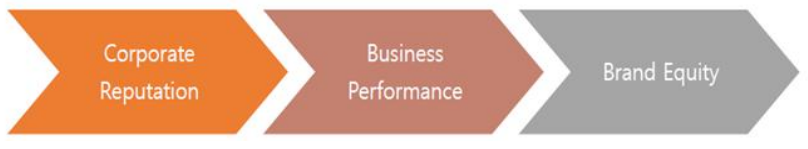

Therefore, in general, CSR disclosure will give positive financially impact in a company's performance and management believe to gain trust from multiple stakeholders for long-term benefit. 


\section{Recommendations and Limitations}

\subsection{Limitations of Study}

The nature of Malaysia guidelines does not have any specific amount or area for the company to disclose CSR activities and this make content analysis more in viable option. Therefore, the research can be done with more identification of various dimensions for the CSR disclosure in a company.

\subsection{Recommendations}

It is recommended to have a better view in terms of evaluating the long-term relationship that exist between CSR and CFP. Stakeholders are more interested to get involve with a company that has sustainable profits with minimum financial provision. Towards the CSR disclosure, it could be added to help to combat clean water shortages in remote areas throughout Malaysia especially in rural area, which is Sabah and Sarawak, using green technology to pump and filter the water fit for consumption. Another method is building a small dam at a river far from the village, then laying of pipes from the dam to a storage tank in the village. This kind of sponsorship or donation is crucial in helping the society and at the same time the company can be well recognized by the residents and it is great for the marketing strategy in the future. The company can also produce a canned food with their label that allows the need citizens for easier logistics especially for those who have a difficult access to the nearest local town. Recipients will find it more convenient to store the food received. By this initiative, not only they can help in providing easy and healthy food, but the can exposed their brand locally and internationally if the products are spreading around worldwide.

\section{References}

Abdullah, A., Mohandes, S. R., Hamid, A. R. A., \& Singh, B. (2016). Research Article. The Practices of Corporate Social Responsibility among Construction Companies in Malaysia. Research Journal of Applied Sciences, Engineering and Technology, 12(7), 742-755. https://doi.org/10.19026/rjaset.12.2750

Ahmad, J., Binti, N., Rashid, A., \& Gow, J. (2017). Board meeting frequency and corporate social responsibility (CSR) reporting: evidence from Malaysia. https://doi.org/10.14453/aabfj.v11i2.5

Ali, A., \& Haseeb, M. (2019). Radio frequency identification (RFID) technology as a strategic tool towards higher performance of supply chain operations in textile and apparel industry of Malaysia. Uncertain Supply Chain Management, 7(2), 215-226. https://doi.org/10.5267/j.uscm.2018.10.004

Baker, M. (2010). Corporate Social Responsibility: What does it mean?. https://doi.org/10.1108/17471111011064807

Chek, I. T., Mohamad, Z. Z., Yunus, J., \& Norwani, N. M. (2013). Corporate social responsibility (CSR) disclosure in consumer products and plantation industry in Malaysia. American International Journal of Contemporary Research, 3(5), 118-125.

Chong, S. Y. C., \& Wad, P. (2017). Corporate social responsibility and offshore outsourcing: electrical and electronics firms in Malaysia. Institutions and Economies, 253-282.

Garriga, E., \& Melé, D. (2004). Corporate social responsibility theories: Mapping the territory. Journal of Business Ethics, 53(1-2), 51-71. https://doi.org/10.1023/B:BUSI.0000039399.90587.34

Hasan, Z., Cho, D. W., Nam, I. H., Chon, C. M., \& Song, H. (2016). Preparation of calcined zirconia-carbon composite from metal organic frameworks and its application to adsorption of crystal violet and salicylic acid. Materials, 9(4), 261. https://doi.org/10.3390/ma9040261

Ibrahim, A. I. A., \& Rashid, M. (2002). Comparison of local povidone-iodine antisepsis with parenteral antibacterial prophylaxis for prevention of infective complications of TURP: a prospective randomized controlled study. European Urology, 41(3), 250-256. https://doi.org/10.1016/S0302-2838(02)00013-1

Jermsittiparsert, K, Sriyakul, T., \& Pamornmast, C. (2013). Quality of Thai Media: Empirical Proposals on "Prime Minister's Eggs" Discourse. Asian Social Science, 9(17), 209-217. https://doi.org/10.5539/ass.v9n17p218

Jermsittiparsert, K, Sriyakul, T., \& Rodoonsong, S. (2013). Power (lessness) of the State in the Globalization Era: Empirical Proposals on Determination of Domestic Paddy Price in Thailand. Asian Social Science, 9(17), 218-225. https://doi.org/10.5539/ass.v9n17p209

Jermsittiparsert, K. (2013). Political Implication in "Sepha Khun Chang - Khun Phaen. Research on Humanities and Social Sciences, 3(10), 86-95. 
Jermsittiparsert, K., \& Sawasdee, A. (2012). Formal Education for Non-Thai or Undocumented Person in Thailand amidst the Challenge of Nationalism and Transnationalism: A Case Study of Wat Sirimongkhol School, Samut Sakhon Province. Kasetsart Journal - Social Sciences, 33(2), 203-213.

Joseph, C., Gunawan, J., Sawani, Y., Rahmat, M., Noyem, J. A., \& Darus, F. (2016). A comparative study of anti-corruption practice disclosure among Malaysian and Indonesian Corporate Social Responsibility (CSR) best practice companies. Journal of Cleaner Production, 112, 2896-2906. https://doi.org/10.1016/j.jclepro.2015.10.091

Khan, N., Ali, K., Kiran, A., Mubeen, R., Khan, Z., \& Ali, N. (2016). Factors that affect the derivatives usage of non-financial listed firms of pakistan to hedge foreign exchange exposure. Journal of Banking and Financial Dynamics, 1(1), 9-20. https://doi.org/10.20448/journal.525/2017.1.1/525.1.9.20

Khan, R. E. A., \& Aslam, I. (2017). Child immunization in Pakistan: Socio-institutional and regional aspects. Asian Journal of Economic Modelling, 5(1), 49-56. https://doi.org/10.18488/journal.8/2017.5.1/8.1.49.56

Khan, Y., \& Mingyi, W. (2018). How the GCC Economic Crises Effect Labor Migration: Evidence from Pakistan. Asian Journal of Economics and Empirical Research, 5(2), 139-146.

Pahi, M. H., Shah, S. M. M., Ahmed, U., \& Umrani, W. A. (2016). Investigating the Issue of Nurse Job Satisfaction: Role of Esprit De Corps, Task Significance, Self-Efficacy and Resilience: A Case Study. International Journal of Academic Research in Business and Social Sciences, 6(4), 339-355. https://doi.org/10.6007/IJARBSS/v6-i4/2112

Radzi, N. A. M., Lee, K. E., Halim, S. A., \& Siwar, C. (2018). An Empirical Study of Critical Success Factors and Challenges in Corporate Social Responsibility (CSR) Implementation: The Case of Selected Corporate Foundations in Malaysia. International Journal of Academic Research in Business and Social Sciences, 8(3), 70-90. https://doi.org/10.6007/IJARBSS/v8-i3/3907

Ramasamy, B., \& Ting, H. W. (2004). A comparative analysis of corporate social responsibility awareness. Journal of Corporate Citizenship, 13(13), 109-123. https://doi.org/10.9774/GLEAF.4700.2004.sp.00013

Reverte, C. (2009). Determinants of Corporate Social Responsibility Disclosure Ratings by Spanish Listed Firms. Journal of Business Ethics, 88, 351-366. https://doi.org/10.1007/s10551-008-9968-9

Rozaimie, A., Huzaimah, S., \& Morni, A. (2016). Multicultural Personality and Cross-Cultural Adjustment among Sojourners in New Zealand. International Journal of Publication and Social Studies, 1(1), 1-9. https://doi.org/10.18488/journal.135/2016.1.1/135.1.1.9

Sallayici, M., \& Kolayis, E. (2018). Examination of Athletes' Anxiety, Motivation, Imagination Value in Competitions with Different Severity Level. Asian Journal of Education and Training, 4(1), 9-12. https://doi.org/10.20448/journal.522.2018.41.9.12

Samaila, M., Uzochukwu, O. C., \& Ishaq, M. (2018). Organizational Politics and Workplace Conflict in Selected Tertiary Institutions in Edo State, Nigeria. International Journal of Emerging Trends in Social Sciences, 4(1), 26-41. https://doi.org/10.20448/2001.41.26.41

Teoh, S. Y., Thi, L. S., \& Teh, Y. K. (2016). Corporate social responsibility practices amongst SMEs in Malaysia.

Yusoff, W. F. W., \& Adamu, M. S. (2016). The relationship between corporate social responsibility and financial performance: Evidence from Malaysia. International Business Management, 10(4), 345-351.

Zabala, B. A. Jr., \& Peñol, C. A. Z. (2018). Social Interactive Behavioral Problems of Social Studies Students of Cabiao National High School. Studies, 4(2), 102-114. https://doi.org/10.20448/807.4.2.102.114 